\title{
Effect of Tillage on Weed Shift and its Managements: A Review
}

\author{
S. Selvakumar ${ }^{1}$, R. Ariraman ${ }^{2}$
}

10.18805/ag.R-2223

\begin{abstract}
Tillage is the most important age old practice, which is usefull to create favourable seed bed for sowing of seeds. It also plays a significant role in weed species persistence and its distribution in agriculture fields. Summer plough kills the weed seeds by exposing it to the sun light. Deep tillage helps for the development of enforced dormancy by burring the newly shredded seeds in the deeper layer of soil. Till now no herbicide is available to kill the weed seeds, tillage improves nitrogen mineralization thus in turn enhance the germination of weed seeds. After weed seed's germination, controlling can be done easily with either spraying of herbicides, mechanical and manual means. Now a day's conservation tillage or zero tillage concept is getting picking up. So it is highly important to study the effect of reduced tillage on weeds. Most of the research evidences found that under reduced tillage condition, weed seed accumulation is higher in upper layer of the soil. Annual weed population is predominant in reduced or no tilled soil. In no tillage system before planting soil was applied with non-persistent non selective herbicides to control weeds effectively.
\end{abstract}

Key words: Herbicide, Tillage, Weed seed bank, Weed species composition.

Tillage has been practiced from ancient days with stirring of soil. Ancient Egyptians, Incas and others began farming by dropping seeds into holes they had made in the soil with sharp sticks. By the $18^{\text {th }}$ century, U.S. farmers had taken oxen or horse teams that pulled crude wooden plows to prepare the soil. It got famous after 1800's. Iron share was invented by john Deere during 1837. After that intensive tillage was followed not only for seed bed preparation but also for weed management. In Indian condition, weeds alone caused economic loss about 11 billion US dollars in 10 major crops in India viz., direct-seeded rice $(21.4 \%)$, transplanted rice $(13.8 \%)$, wheat $(18.6 \%)$, sorghum $(25.1 \%)$, maize $(25.3 \%)$, pearlmillet $(27.6 \%)$, groundnut $(35.8 \%)$, soybean $(31.4 \%)$, greengram $(30.8 \%)$, sesame $(23.7 \%)$, mustard (21.4\%) (Gharde et al., 2018). Later it had been found that intensive tillage reduced soil organic matter, destroys soil structure, creation of hard impervious layer beyond the ploughed zone (Ozpinar and clay, 2006). To avoid those ill effects, concept of conservation tillage aroused (Anonymous, 2001). It again reoriented with minimum tillage and zero tillage. But in minimum and zero tillage weed management becomes the major menace (Krauss et al., 2010, Gruber and Claupein, 2009), especially controlling of perennial weeds become more difficult (Gruber and Claupein, 2009; Sans et al., 2011). So during adoption of theses conservation tillage practices herbicides were extensively used to control weeds (Peigné et al., 2009).

\section{Effect of tillage on soil weed seed bank}

Soil act as a reservoir for weed seeds. It is present not only on the top of the soil surface but also spread over the soil profile (Singh et al., 2012; Begum et al., 2006). Tillage was the most important factor in vertical distribution of weed seeds, in that type and time of tillage influences more on vertical distribution of weed seeds in seed bank (Swanton et al., 2000). It consisted of newly shredded seeds to old
1Department of Crop Management, Kumaraguru Institute of Agriculture, Erode-638 315, Tamil Nadu, India.

2Department of Agronomy, Agricultural College and Research Institute, Tamil Nadu Agricultural University, Madurai-625 104, Tamil Nadu, India.

Corresponding Author: S. Selvakumar, Department of Crop Management, Kumaraguru Institute of Agriculture, Erode-638 315, Tamil Nadu, India. Email: selva4647@gmail.com

How to cite this article: Selvakumar, S. and Ariraman, R. (2022). Effect of Tillage on Weed Shift and its Managements: A Review. Agricultural Reviews. DOI: 10.18805/ag.R-2223.

Submitted: 05-04-2021 Accepted: 03-01-2022

Online: $21-02-2022$

seeds. Weeds seed bank also contain tubers, bulbs, rhizomes and other vegetative structures of most serious perennial weeds. Agricultural soils contained thousands of weed seeds and a dozen or more vegetative weed propagules per square foot (Menalled and Schonbeck, 2011). Mostly weed seed load was highest in fallow soil due to lack of tillage and plant competition (Archibold and Hume, 1983). In no-till fields, the majority of weed seeds remained at or near the soil surface. When chisel plough was used, $66 \%$ of seeds were distributed in the 5 to $10 \mathrm{~cm}$ layer, but, usage of mould board plough brought $71 \%$ of the seeds at the depth of 10 to $15 \mathrm{~cm}$ (Swanton et al., 2000), because of that light and oxygen become unavailable and caused enforced dormancy (Gulden et al., 2003). Even though non photoblastic seeds get germinated, due to deep placement the plume or radicle will not reach the soil surface. Before reaching soil surface stored reserves in seeds will be exhausted (Gulden and Shirtliffe, 2009). It affected the weeds germination. Mostly weed seed present in the soil will be viable for many years. Seed coating and some of the phenolic substances present in the seed coat protect the seeds from attack of pest and pathogens. 
Till now no herbicide was designed to kill the weed seeds. So to reduce weed seed bank in the soil, germination of weed seeds is essential. It can be aided by tillage operation. During tillage some of the underground weed seeds get exposed to the surface of soil and creates favorable condition for its germination. For example weed seeds of predominant species were more prevalent near the soil surface after chisel plowing (Swanton et al., 2000). Adequate amount of rainfall and improved nitrogen mineralisation due to tillage operation (Mickelson and Grey, 2006), accelerate the weeds seeds germination. So further weed management can be done easily by applying herbicide or shallow tillage operations. In this way mostly summer tillage is useful in reducing weed seed bank. In other side tillage reduces the problem of herbicide resistant weeds and weed shift than no tillage, because in no tillage system, weeds are controlled mainly by herbicides. Controlling of particular weed species by repeated use of same selective herbicide caused weed shift. It also affected the efficiency of herbicide (Mickelson et al., 2001). Surface accumulation of seeds under reduced tillage would increase predator access to seeds and therefore it could increase their removal rates. Lack of soil disturbance via tillage could also encourage higher predator populations. No till fields increased the number, diversity or activity of seed-consuming fauna as compared to conventionally tilled fields (Blubaugh and Kaplan, 2015) may be due to increased habitat (Baraibar et al., 2009) or decreased mortality rate (Shearin et al., 2008).

Phalaris minor and Rumex dentatus were studies to know it distribution efficiency after puddling. In top $2.5 \mathrm{~cm}$ soil layer $0.02 \%$ of $P$. minor and $1.24 \%$ of $R$. dentatus was found on the surface after puddling, $29.3 \% P$. minor of and $33.6 \%$ of $R$. dentatus of total weed seed present in upper $12.5 \mathrm{~cm}$ soil depth. The reason for higher density of $R$. dentatus seeds in the upper soil layer was due to lower seed density of $16.17 \mathrm{~kg} /$ hectoliter when compared with 61.31 $\mathrm{kg} /$ hectolitre for $P$. minor. It was mainly due to $R$. dentatus seeds had perianth, which helps in floating. In 10.0-12.5 $\mathrm{cm}$ soil layer for both weeds recorded lowest weed seed distribution (Chhokar et al., 2007).

\section{Influence of tillage on weed seed distribution in different soil types}

Research papers in weed seed bank studies mostly concentrated on fine texture soil. Clay soil recorded slower seed burial than sandy soils. After one year of experimentation, in sandy soil seeds reached greater depth compared to clay soil. Rainfall and seed weight also influenced the burial dynamics of weed seed (Benvenuti, 2003). Loamy sand soil also recorded $90 \%$ of weed seed population in top $5 \mathrm{~cm}$ under no till condition (Swanton et al, 2000 ), usage of chisel plough leaves $63 \%$ of seeds at $0-5$ $\mathrm{cm}$ depth but in mould board ploughing most of the weed seeds buried in deeper layer and less uniform of vertical weed seeds distribution was observed (Swanton et al, 2000). In silty loam soil, the weed seed bank was more homogenously distributed over the tillage depth upto $15 \mathrm{~cm}$ with mouldboard ploughing. But in a chisel plough or no-till system more than $60 \%$ of the weed seed bank was concentrated in the upper $5 \mathrm{~cm}$ of soil depth (Clements et al., 1996). This variation in distribution of weed seed in soil may be due to response of different soil types and its physical character for the applied tillage practices (Benvenuti, 2003). Because sandy soil offers lesser resistant for turning of soil during tillage, but clay soil offer more resistant for turning of soil during tillage (Swanton et al., 2000). Viable seeds and dormant seeds generally higher with conservation tillage than no tillage (Gallandt et al, 2004; Peralta et al., 2011), in no tillage system weed seeds are present at surface of soil, due to that dehydration will take place. So it reduces viability of seeds (Clements et al., 1996).

\section{Influence of ploughing on weed population}

Some of the research evidences showed that more annual weeds in no tillage system but in contrast to that some of them reported less weed population under no tillage system Several studies have been found that the effects of tillage vary with weed species, timing and depth of tillage (Selvakumar and Sivakumar, 2021). In particular more grass weeds especially Phalaris minor, Avena ludoviciana and Cynodan dactylon were commonly observed in conventional tillage with or without residue incorporation compared to zero tillage with or without residue incorporation (Singh et al., 2017). When seed material is absent, no tilled soil weed density is higher. But in the subsequent years weed density is higher in the case of tilled soil (Mohler, 1993). Aelsmaranthus and Digitaria showed larger seed production in no-tilled soil, whereas winter annual herbs produced more seeds in tilled soil with corn crop. Dominant species were Amaranthus, Portulaca and Digitaria and least dominant was Chenapodium (Mohler and Callaway, 1995). Land ploughed with chisel and mouldboard plough had higher above ground part of lambs quarters compare to sowing with seed drill under no tillage system in silty loam soil with wheat corn rotation (Clements et al., 1996). Most of the weeds are season bound, they emerge only at particular season, so whenever tillage operations coincides with optimum season for weed seed germination accelerates germination of weeds (Chauhan and Johnson, 2009). Tillage without residue incorporation into the soil, will reduce the germination percentage of weeds by fluctuating temperature and light but some of the research evidence showed that germination of weed seeds was improved when moisture deficit occurs (Mohler and Teasdale, 1993). Moss (1979) reported that shallow tillage increase seed production rate of Alopecurus myosuroids in continuous winter wheat cropping. Tillage with mulching of rye reduced weed density of some weed species due to allelopathy (Shilling et al., 1985). Chisel plough and mouldboard plough operated field recorded higher weed population. Construction of ridge through tillage stimulated weed seed germination and improved seed production capacity of weeds (Forcella, 1988). Conservation tillage 
changed the weed composition. Because it reduced the disturbance in agro ecosystem (Swanton et al., 2000), as the result weed seeds may present near or on the soil surface, so it increases weed population. Mostly perennial weed population especially which produced seeds through asexual means get increased with no tillage system (Clements et al, 1996). Annual board leaved weeds were higher with mouldboard ploughing compared to chisel ploughing and disc harrowing (Knežević, 2008). Some of the research evidence showing that zero tillage recorded lower weed density of Phalris minor than conservation tillage, due to higher soil strength. So the development of herbicide resistance in Phalaris minor may be avoided with zero tillage and herbicide application. But density of Rumex dentatuswas higher than zero tillage system (Chhokar et al., 2007). This effect may be due to higher moisture content available at surface layer in zero tillage than conservation tillage after first irrigation. Because soil dries up quickly in conventional tillage system after first irrigation (Chhokar et al., 2007). No tillage system increased surface weed seeds mortality by exposing into extreme weather and predation (Anderson, 2005). In contrast, some of the weed seeds having protection mechanism for safeguarding from extreme weather events like prianth in Rumex dentatus (Chhokar et al., 2007) and spikelet in Aegilops cylindrical, which encloses seed (Mohler, 1993). So these weed seeds get increased in zero tillage.

Some contrast experimental results showed that the seed bank persistence of volunteer canola was similar after three years under conventional and no-tillage system (Gulden et al., 2004). Canola seed could be persist for three years, if it was buried (Liebman et al., 2001).

\section{Blind tillage as a special practice for weed control}

In blind tillage, tillage operation is carried out after sowing and before emergence of crop or crop at early growth stages. It is most effective in case of row crops and cereals. Harrows are generally used to control weeds. In general, corn, soybean and the crop seeds shown at a depth of one inch or more and have quick development of large taproots after germination will tolerate blind cultivation. Blind tillage poorly controls the weed seedlings such as common ragweed, velvetleaf, giant ragweed and annual morning glories that develop roots more than an inch depth, because perennial weeds with well-established root system recorded lesser control with blind tillage (Curran et al., 2019). Generally it is done as soon as the weeds appear and it can be extended until the plant reaches advance stage. Now a days hand operated or power operated hoes are also available for easy weeding. Weeding width can be adjusted according to the spacing of the plants. Rotary hoe or spike tooth harrow is used with the success in the controlling of weeds in young corn, cotton and other row crops. Generally this operation is carried out at two weeks after sowing, whether the crop is up or not. In some the cases, it is done across the rows. $8 \%$ of grain yield increase was recorded with first harrowing alone (Bates et al., 2012) whereas second harrowing recorded only additional 3\% yield increase. Soybean yield increased with rotary hoeing. Stale seed bed prepared with four passes of rotary hoe could reduce the weed density by $57 \%$ (Place et al., 2009). It also improved system productivity and resource use efficiency (Sobhana et al., 2021).

\section{Influence of tillage on chemical weed management}

No till soil generally have higher weed density, due to that no tillage system requires more quantity of herbicides compared to conventional farming system (Acciaresi et al., 2003). This will lead to environmental pollution. To avoid this integrated weed management practices can be followed. Mostly tillage combined with herbicide application provided better weed control, thereby it improved crop yield also (Knežević et al., 2008). Changes in tillage practices, changes composition of weed flora, so based on that herbicide should be applied (Selvakumar and Sivakumar, 2021). Response of weed dynamics based on species, location and timing. Increased rate of nitrogen application decreased the annual grass weed population in winter wheat (Valenti and Wicks, 1992) but contrastingly Setaria viridis (Peterson and Nalewaja, 1992) and Avena fatua (Carlson and Hill, 1986) in wheat crop was favoured by application of nitrogen. Generally tillage reduced organic matter by quickening the oxidation process or increased turnover (Balesdent et al., 2000 ), especially in case of high organic matter content soil. So herbicide adsorption by the soil organic matter will be reduced in tilled soil condition (Hartzler, 2011). This may improve efficiency of herbicide. In conservation and no tillage farming microbial load was $32 \%$ higher compared to conventional tillage (Helgason, 2010), which may favour faster herbicide degradation. But it is not in the case with tilled soil. It initially check microorganism growth (Young and Ritz, 2000), so herbicide degradation is reduced. Pre emergence herbicides mostly forms a thin layer on soil surface with available moisture after application. This inturn will be absorbed by the emerging weeds and killed. It is ineffective on established weeds. Tillage practices help to level the field perfectly. This will helps to formation of thin layer of herbicide on the soil. In conventional tillage, already established weeds will be killed and also it stimulates germination of weed seeds. So at this stage application of selective pre emergence gives better weed control. But it is not in the case with no tillage. In no tillage system, before sowing of crop non selective broad spectrum herbicides are used to kill the weeds. Then during sowing maximum weed seeds will not germinate due to lack of stimuli caused by tillage. So weeds germination will not even. This will resulted in ineffective weed control through pre emergence herbicides (Ishaya et al., 2008).

\section{Weed management in reduced tillage}

Reduced tillage increased problem of weed (Nyamangara et al., 2014). To manage this problem we are normally fallowing herbicide application (Melander et al., 2013), it increases herbicide load in soil. This causes environmental 
pollution and it also affects the cropping sequence due to residue persistent. Repeated use of same herbicides may causes herbicide resistant weed population especially in case of zero tillage (Tranel and Wright, 2002). This make herbicide weed control as a tedious one. So to avoid those problems integrated weed management can be followed (Melander et al., 2013). First and foremost the field should not be kept as fallow, continuous cropping should be there (Hosseini et al., 2014). There by we can reduce the weed seed accumulation in soil.

In general crop affected by initial quick growth of weeds. So crop species or variety should be screened for its early vegetative growth. There by it suppress weed growth at initial stage. Plastic or residue can be used as a mulch to suppress the weed growth. It also reduces evaporation from the soil surface (Hammermeister, 2016). Cover crops like cowpea, calopogonium can be grown in-between wide spaced crops and it can suppress the weed growth (Dogbe, 1998). In some of the cases, increased seed rate with thicker plant population will reduce the incidents of weeds. This cannot be followed for the crops, when its economic product is seed. Because crowded plant population will produce elongated stem with more foliage due to competition for light interception. So this method is highly beneficial when the foliage of the crop is economic produce. Most of the weeds are season specific. They will germinate when the optimum condition prevails for its growth and development. Mild weather favours growth of most of the weeds. So site and season specific weed management can be adopted with available weed species, density, soil type and season (López granados, 2011). Some of the bio herbicides are also available in the market to control weeds. But those are highly host specific, which will not applicable when mixed population of weeds present in the cropped field. In case of mycoherbicides, compatibility between two or more fungus can be studied. If it is positive, broad spectrum of weeds can be controlled. This research area is lacking. Weeds are having enormous seed production capacity. So major aim of the weed management should be the controlling of weeds before seed setting. In organic farming leaf extract of allelopathic plants can be used to control weeds (Jabran et al., 2015). By optimizing integrated weed management strategies to the each and individual crops, the weed problem in reduced tillage can be managed.

\section{CONCLUSION}

This review concluded that varies tillage operations showed a considerable influence on weed population, seed bank and its persistence, moreover tillage also has influence on weed management practices. The tillage operation coincides with favourable season for weed seed germination recorded higher seed germination and growth of weed seeds. Chisel and mould board plough operated fields recorded higher weed density because of inversion of viable weed seeds from the deeper layer. Now a days zero tillage or conservation tillage concept is picking up due to disadvantage of conventional intensive tillage. So it is highly essential to study the changes in weed composition and weed seed distribution under both the tillage system. Grassy weeds are higher under no tillage system, whereas under intensive tillage system, density of broad leaved weeds gets increased. Due to lesser disturbance in soil under both conservation and zero tillage system, perennial weed become more stable and its population also considerably increased. So to control weeds in those area requires more quantity of herbicides. Moreover reduced tillage recorded increased organic matter composition compared to conventional tillage, so absorption of herbicide by organic matter get increased, this in turn reduces the efficacy of herbicide. Hence, the weed control operation need to be standardized to get maximum herbicide efficiency under reduced tillage condition.

Conflict of interest: None.

\section{REFERENCES}

Acciaresi, H.A., Balbi, H.V., Bravo, M.L. and Chidichimo, H.O. (2003). Response of weed populations to tillage, reduced herbicide and fertilizer rates in wheat (Triticum aestivum) production. Planta Daninha. 21(1): 105-110.

Anderson, R.L. (2005). A multi tactic approach to manage weed population dynamics in crop rotations. Agronomy Journal. 97(6): 1579-1583.

Anonymous (2001). Conservation Agriculture in Europe. http:// www.ecaf.org.uk.

Archibold, O.W. and Hume, L. (1983). A preliminary survey of seed input into fallow fields in Saskatchewan. Canadian Journal of Botany. 61(4): 1216-1221.

Balesdent, J., Chenu, C. and Balabane, M. (2000). Relationship of soil organic matter dynamics to physical protection and tillage. Soil and Tillage Research. 53(3-4): 215-230.

Baraibar, B., Westerman, P.R., Carrión, E. and Recasens, J. (2009). Effects of tillage and irrigation in cereal fields on weed seed removal by seed predators. Journal of Applied Ecology. 46(2): 380-387.

Bates, R.T., Gallagher, R.S., Curran, W.S. and Harper, J.K. (2012). Integrating mechanical and reduced chemical weed control in conservation tillage corn. Agronomy Journal. 104(2): 507-517.

Begum, M., Juraimi, A.S., Rastan, S.O.O.B.S., Amartalingam, R. and Man, A.B. (2006). Seedbank and seedling emergence characteristics of weeds in rice field soils of the muda granary area in north-west peninsular Malaysia. BiotropiaThe Southeast Asian Journal of Tropical Biology. 13(1).

Benvenuti, S. (2003). Soil texture involvement in germination and emergence of buried weed seeds. Agronomy Journal. 95(1): 191-198.

Blubaugh, C.K. and Kaplan, I. (2015). Tillage compromises weed seed predator activity across developmental stages. Biological Control. (81): 76-82.

Carlson, H.L. and Hill, J.E. (1986). Wild oat (Avena fatua) competition with spring wheat: effects of nitrogen fertilization. Weed Science. 29-33.

Chauhan, B.S. and Johnson, D.E. (2009). Influence of tillage systems on weed seedling emergence pattern in rainfed rice. Soil and Tillage Research. 106(1): 15-21. 
Chhokar, R.S., Sharma, R.K., Jat, G.R., Pundir, A.K. and Gathala, M.K. (2007). Effect of tillage and herbicides on weeds and productivity of wheat under rice-wheat growing system. Crop protection. 26(11): 1689-1696.

Clements, D.R., Benott, D.L., Murphy, S.D. and Swanton, C.J. (1996). Tillage effects on weed seed return and seed bank composition. Weed Science. 314-322.

Curran, W., Cahoon, C. and Sandy, D. (2019) Mechanical Weed Control: Post-Plant. A Practical Guide for Integrated Weed Management in Mid-Atlantic Grain Crops. p.107.

Dogbe, W. (1998). Green-manure crops for sustainable agriculture in the inland valleys to northern Ghana. Cover Crops in West Africa: Contributing to Sustainable Agriculture. p.213.

Forcella, F. and Lindstrom, M.J. (1988). Weed seed populations in ridge and conventional tillage. Weed Science. 36(4), 500-503.

Gallandt, E.R., Fuerst, E.P. and Kennedy, A.C. (2004). Effect of tillage, fungicide seed treatment and soil fumigation on seed bank dynamics of wild oat (Avena fatua). Weed science. 52(4): 597-604.

Gharde, Y., Singh, P.K., Dubey, R.P. and Gupta, P.K. (2018). Assessment of yield and economic losses in agriculture due to weeds in India. Crop Protection. 107. pp. 12-18.

Gruber, S. and Claupein, W. (2009). Effect of tillage intensity on weed infestation in organic farming. Soil and Tillage Research. 105(1): 104-111.

Gulden, R.H. and Shirtliffe, S.J. (2009). Weed seed banks: biology and management. Prairie Soils and Crops Journal. 2:4652.

Gulden, R.H., Shirtliffe, S.J. and Thomas, A.G. (2003). Secondary seed dormancy prolongs persistence of volunteer canola in western Canada. Weed Science. 51(6): 904-913.

Gulden, R.H., Thomas, A.G. and Shirtliffe, S.J. (2004). Secondary dormancy, temperature and burial depth regulate seed bank dynamics in canola. Weed Science. 52(3): 382-388.

Hammermeister, A.M. (2016). Organic weed management in perennial fruits. Scientia Horticulturae. 208: 28-42.

Hartzler, B., (2011). A reintroduction to soil applied herbicides.

Helgason, B.L., Walley, F.L. and Germida, J.J. (2010). No-till soil management increases microbial biomass and alters community profiles in soil aggregates. Applied Soil Ecology. 46(3): 390-397.

Hosseini, P., Karimi, H., Babaei, S., Mashhadi, H.R. and Oveisi, M. (2014). Weed seed bank as affected by crop rotation and disturbance. Crop Protection. 64: 1-6.

Ishaya, D. B., Tunku, P. and Kuchinda, N. C. (2008). Evaluation of some weed control treatments for long season weed control in maize (Zea mays L.) under zero and minimum tillage at Samaru, in Nigeria. Crop Protection, 27(7): 1047-1051.

Jabran, K., Mahajan, G., Sardana, V. and Chauhan, B.S. (2015). Allelopathy for weed control in agricultural systems. Crop Protection. 72: 57-65.

Knežević, M., Ranogajec, L. and Šamota, D. (2008). Effects of soil tillage and herbicides on weeds and winter wheat yields. Cereal Research Communications. 36: 1403-1406.

Krauss, M., Berner, A., Burger, D., Wiemken, A., Niggli, U. and Mäder, P. (2010). Reduced tillage in temperate organic farming: Implications for crop management and for age production. Soil Use and Management. 26(1): 12-20.
Liebman, M., Mohler, C.L. and Staver, C.P. (2001). Ecological Management of Agricultural Weeds. Cambridge University Press.

López granados, F. (2011). Weed detection for site specific weed management: Mapping and real time approaches. Weed Research. 51(1): 1-11.

Melander, B., Munier-Jolain, N., Charles, R., Wirth, J., Schwarz, J., van der Weide, R., Bonin, L., Jensen, P.K. and Kudsk, P. (2013). European perspectives on the adoption of nonchemical weed management in reduced-tillage systems for arable crops. Weed Technology. 27(1): 231240.

Menalled, F. and Schonbeck, M. (2011). Manage the Weed Seed Bank-Minimize "Deposits" and Maximize "Withdrawals". Margins. 1(8).

Mickelson, J.A. and Grey, W.E. (2006). Effect of soil water content on wild oat (Avena fatua) seed mortality and seedling emergence. Weed Science. 54(2): 255-262.

Mickelson, S.K., Boyd, P., Baker, J.L. and Ahmed, S.I. (2001). Tillage and herbicide incorporation effects on residue cover, runoff, erosion and herbicide loss. Soil and Tillage Research. 60(1-2): 55-66.

Mohler, C.L. (1993). A model of the effects of tillage on emergence of weed seedlings. Ecological Applications. 3(1): 53-73.

Mohler, C.L. and Callaway, M.B. (1995). Effects of tillage and mulch on weed seed production and seed banks in sweet corn. Journal of Applied Ecology. pp.627-639.

Mohler, C.L. and Te Asdale, J.R. (1993). Response of weed emergence to rate of Vicia villosa Roth and Secale cereale L. residue. Weed Research. 33(6): 487-499.

Moss, S.R. (1979). The influence of tillage and method of straw disposal on the survival and growth of black grass, Alopecurus myosuroides and its control by chlortoluron and isoproturon. Annals of Applied Biology. 91(1): 91-100.

Nyamangara, J., Mashingaidze, N., Masvaya, E.N., Nyengerai, K., Kunzekweguta, M., Tirivavi, R. and Mazvimavi, K. (2014). Weed growth and labor demand under hand-hoe based reduced tillage in smallholder farmers' fields in Zimbabwe. Agriculture, Ecosystems and Environment. 187: 146-154.

Ozpinar, S. and Cay, A. (2006). Effect of different tillage systems on the quality and crop productivity of a clay-loam soil in semi-arid north-western Turkey. Soil and Tillage Research. 88(1-2): 95-106.

Peigné, J., Cannavaciuolo, M., Gautronneau, Y., Aveline, A., Giteau, J.L. and Cluzeau, D. (2009). Earthworm populations under different tillage systems in organic farming. Soil and Tillage Research. 104(2): 207-214.

Peralta Caroca, R., Silva Candia, P. and Acevedo Hinojosa, E. (2011). Characterization of the weed seed bank in zero and conventional tillage in central Chile. Chilean Journal of Agricultural Research. 71(1): 140-147.

Peterson, D.E. and Nalewaja, J.D. (1992). Environment influences green foxtail (Setaria viridis) competition with wheat (Triticum aestivum). Weed Technology. 607-610.

Place, G.T., Reberg-Horton, S.C., Dunphy, J.E. and Smith, A.N. (2009). Seeding rate effects on weed control and yield for organic soybean production. Weed Technology. 23(4): 497-502. 
Sans, F.X., Berner, A., Armengot, L. and Mäder, P. (2011). Tillage effects on weed communities in an organic winter wheatsunflower-spelt cropping sequence. Weed Research. 51(4): 413-421.

Selvakumar, S. and Sivakumar, K. (2021). Conservation Agriculture: A way for soil water conservation. Agricultural Reviews. DOI: 10.18805/ag.R-2045.

Shearin, A.F., Reberg-Horton, S.C. and Gallandt, E.R. (2008). Cover crop effects on the activity-density of the weed seed predator Harpalus rufipes (Coleoptera: Carabidae). Weed Science. 442-450.

Shilling, D.G., Liebl, R.A. and Worsham, A.D. (1985). Rye (Secale cereale L.) and wheat (Triticum aestivum L.) mulch: The suppression of certain broadleaved weeds and the isolation and identification of phytotoxins.

Singh, A., Kaur, R., Kang, J.S. and Singh, G. (2012). Weed dynamics in rice-wheat cropping system. Global Journal of Biology Agriculture and Health Sciences. 1: 7-16.

Singh, R.P., Verma, S.K., Prasad, S.K., Singh, H. and Singh, S.B. (2017). Effect of tillage and weed management practices on grassy weeds in wheat (Triticum aestivum L.). International Journal of Science, Environment and Technology. 6(1): 404-412.
Sobhana, E., Swaminathan, C., Kannan, P. and Gurusamy, A. (2021). Conservation Agriculture Practices: Impact on Productivity, Energy Utilisation and Profitability of Legume-based Cropping System. Legume Research An International Journal. 1(7): DOI: 10.18805/LR4627.

Swanton, C.J., Shrestha, A., Knezevic, S.Z., Roy, R.C. and BallCoelho, B.R. (2000). Influence of tillage type on vertical weed seed bank distribution in a sandy soil. Canadian Journal of Plant Science. 80(2): 455-457.

Tranel, P.J. and Wright, T.R. (2002). Resistance of weeds to ALSinhibiting herbicides: What have we learned, Weed Science. 50(6): 700-712.

Valenti, S.A. and Wicks, G.A. (1992). Influence of nitrogen rates and wheat (Triticum aestivum) cultivars on weed control. Weed Science. 40(1): 115-121.

Young, I.M. and Ritz, K. (2000). Tillage, habitat space and function of soil microbes. Soil and Tillage Research. 53(3-4):201213. 